\title{
Sand pits as habitats for beetles (Coleoptera): does area affect species number and composition?
}

\author{
Lina Lönnberg • Mats Jonsell
}

Received: 3 March 2011/Accepted: 9 January 2012/Published online: 31 January 2012

(C) The Author(s) 2012. This article is published with open access at Springerlink.com

\begin{abstract}
Species living in open sandy habitats are declining in northern Europe because of habitat loss and degradation. However, mining of sand creates potential new habitats for these species in the form of sand pits. In this study we investigated the beetle fauna in sand pits in order to determine what kind of sand pits are the most valuable for conservation, in terms of sand pit area (primarily) and the proportion of sand material, vegetation cover, tree cover and edge habitats. Thirteen sand pits in Uppsala County, Sweden, ranging in size from 0.02 to 18 ha, were included in this study. A total of 2,500 individuals of beetles, belonging to 256 species, were sampled by pitfall traps. Thirty-nine of the species were classified as specialized sand-dwelling species and two were Swedish Red List species. We found that the area of sand pits affects both species number and species composition of beetles. A positive species-area relationship was found, best explained by a quadratic power function, for the habitat-specific species (i.e., sand species). Our recommendation is to prioritize sand pits with areas between 0.3 and 5 ha, with preference towards the lower end of this range, for conserving sand-dwelling beetles.
\end{abstract}

Keywords Beetles - Carabidae - Coleoptera - Edge effect · Sand pits · Species-area relationship $\cdot$ Sweden

\section{Introduction}

Species associated with open sandy habitats have found refuges in sand pits created by mining of sandy soil. In northern Europe, several of these species are rare or endangered (e.g. Bergsten 2007; Eversham et al. 1996; Frycklund 2003; Ljungberg 2002; Schiel and Rademacher 2008; Sörensson 2006), because the total area of open, disturbed habitats has declined following changes in land-use. One important change is regrowth or afforestation of sites with sandy, low-productivity soils, where cattle commonly grazed centuries ago

L. Lönnberg · M. Jonsell ( $\square)$

Department of Ecology, SLU, Box 7044, 75007 Uppsala, Sweden

e-mail: mats.jonsell@slu.se 
(Emanuelsson 2009). Another change is a reduction in the frequency of forest fires, which commonly resulted in open sandy spots after consuming the organic topsoil. Consequently, sand pits have become valuable habitats for beetles (Eversham et al. 1996; Ljungberg 2001, 2002; Molander 2007; Sörensson 1983) and several other organism groups, e.g., aculeate wasps (Bergsten 2007; Drewes 1998; Sörensson 2006), butterflies (Frycklund 2003; Koeppel et al. 1994) and vascular plants (Andersson 1995; Bzdon 2008; Widgren 2005). For these species, the usual practice of restoring abandoned sand pits by levelling out slopes, planting trees, and adding topsoil is detrimental (e.g., Bell 2001; Dulias 2010). Many conservationists recognize the value of sand pits as habitats for threatened species. However, there is a paucity of information regarding the kinds of pits being most valuable for conserving the various taxa of fauna and flora that rely on them.

One important factor influencing species richness and composition is patch size. Large areas tend to hold larger numbers of species than smaller areas (Connor and McCoy 1979; Rosenzweig 1995). This species-area relationship (SAR) is a robust generalization, based on numerous empirical studies (reviewed in Drakare et al. 2006). Island biogeography theory was developed by MacArthur and Wilson (1967) to explain SA-relationships, and the theory has since been extended to include terrestrial habitat patches with disjunctive surrounding habitats. When considering terrestrial habitat patches, however, the SAR can be distorted by species invading from the surrounding matrix into the habitat edges (Cook et al. 2002; Ewers and Didham 2006). Accordingly, in several cases positive SA-relationships have been observed for habitat-specific species, but not for total species numbers (Lövei et al. 2006; Magura et al. 2001; Vries de et al. 1996).

Several hypotheses have been proposed to explain the SAR, two of the most prominent being the 'area per se hypothesis' (Preston 1960; MacArthur and Wilson 1967) and the 'habitat heterogeneity hypothesis' (Williams 1964). The area per se hypothesis is based on assumptions that probabilities of extinction and colonization will generally be lower and higher, respectively, in larger areas, while the habitat heterogeneity hypothesis assumes that habitats will be more diverse in larger areas and therefore more species will be able to live in them. Both hypotheses probably partially explain the SAR, although it is difficult to distinguish their relative effects (Connor and McCoy 1979). Efforts to evaluate their relative importance have had varying results (e.g., Báldi 2008; Kallimanis et al. 2008). Attempts have also been made to unify the two hypotheses (Triantis et al. 2003).

In this study, the beetle assemblages of 13 sand pits in east-central Sweden were examined to evaluate the effects of the area of sand pits on the number and composition of species they host. A positive SAR was expected for the target species, i.e., specialist species of open sandy habitats (here termed sand species). The effects of four additional habitat characteristics were also tested: the proportion of sand material at the surface, vegetation cover, tree cover and edge habitat. As beetles are a very diverse group we specifically analyzed carabids (Carabidae) in order to see if they could be used as an indicator of diversity for the whole order. Carabids could be useful indicators as they are well known (taxonomically and ecologically), they can be easily and cost-efficiently sampled by pitfall traps, and they include many species confined to habitats in an early successional stage (Ljungberg 2002; Rainio and Niemelä 2003). Finally, we used our data to draw conclusions with respect to conservation measures for sand pits. More specifically we addressed the following questions:

- Does the area of sand pits influence beetle species number and composition?

- Does the surrounding matrix influence SAR? 
- Do other examined variables (proportion of sand material, vegetation cover, tree cover and edge habitat) influence beetle diversity?

- Can carabids be used as a diversity indicator for all beetle species in sand pits?

- Based on our results, what recommendations can be made for species conservation in sand pits?

\section{Materials and methods}

Study region and study sites

The study focused on 13 sites located along three eskers (Enköpings-, Vattholma- and Uppsalaåsen) in Uppsala County, east-central Sweden (Fig. 1). The eskers are composed of deposits from the last glaciation that constitute most of the sandy soils in the region (Fredén 2002). The whole region was uplifted from below sea level after the last glaciation; the land at higher levels consists of moraine soil, whereas clay deposits dominate lower land areas. The topography within the region is relatively flat and the highest altitude above sea level on any of the eskers is $75 \mathrm{~m}$.

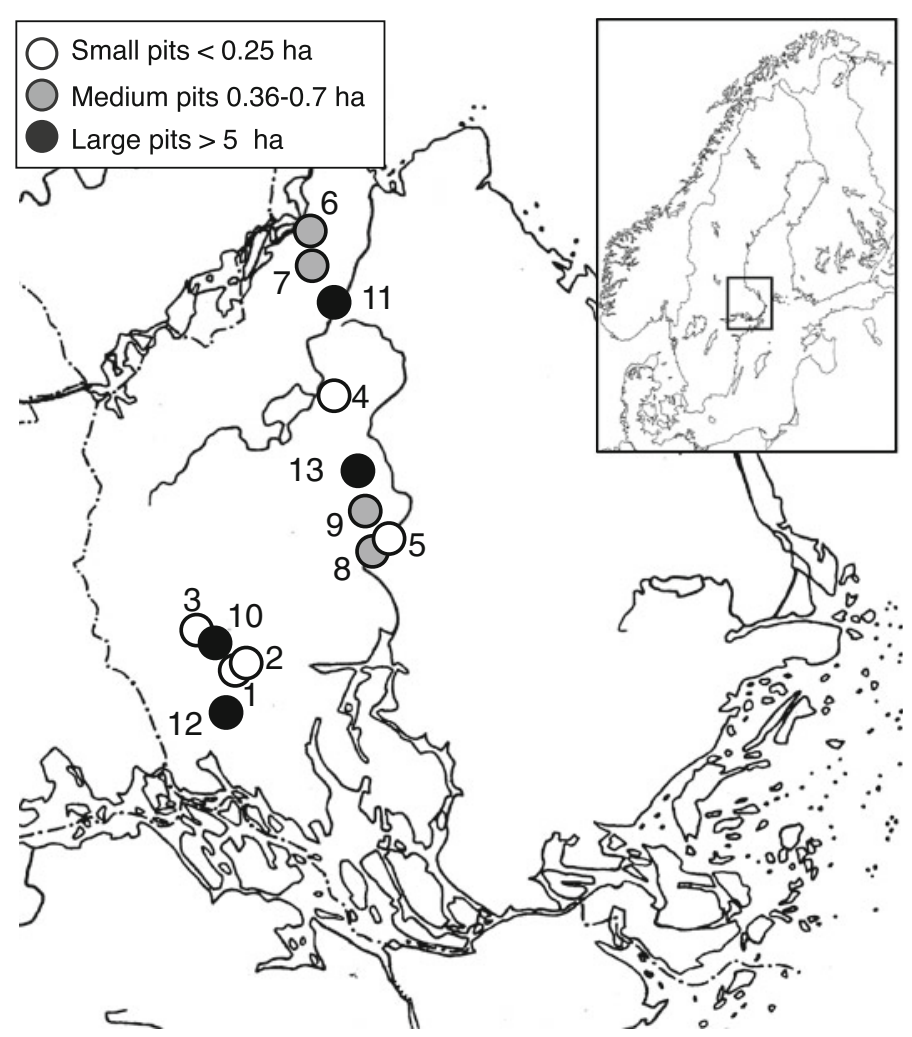

Fig. 1 Positions of the thirteen study sites in Uppsala County in east-central Sweden. Names of numbered sites are listed in Table 1 
The 13 study sites were all sand pits that had either been abandoned or had low levels of disturbance from mining activity (Fig. 1; Table 1). They were selected using records collected from the County Administration of Uppsala, i.e., their database (133 pits) and older inventory maps (291 pits). The sources had partly overlapping records and many of the older pits have become overgrown. The criteria for selecting pits were that they should (1) represent a range of patch sizes (area 200-180,000 $\mathrm{m}^{2}$ ), (2) mainly consist of bare ground (40-95\%), and (3) include sand and gravel material in various proportions. The sites also needed to be isolated from each other by discrete habitat (minimum distance between sites was $225 \mathrm{~m}$ ). The surrounding landscape (edge habitat) consisted of forest, open areas or a mixture of both. In this paper, the term 'sand pit' is used as a generic term for both sand and gravel pits.

\section{Environmental variables}

Six variables were measured at each study site (Table 1). The total area of the sites was defined as the original area of the pit, excluding edge areas of intruding neighbouring habitats. This area was calculated by a GIS program using GPS measurements taken along the site borders, except for two of the largest sites, for which areas were calculated from aerial photographs. Results obtained with the two methods were compared for the other sites, and were strongly correlated. Due to the topological shape of the pits, the area measurements are not the actual surface areas, however, the difference between actual area and the area calculated using our methodology has been shown to be negligible (see Triantis et al. 2008).

The three variables; proportion of sand material, vegetation cover and tree cover were all estimated (by $5 \%$ intervals) in the field by visual estimate considering the whole sand pit. Vegetation cover was defined as the proportion of the total area covered by vegetation layer dense enough so the ground material could not be seen through it. An alternative

Table 1 Study sites in east-central Sweden (Fig. 1) and their characteristics as measures by six variables

\begin{tabular}{|c|c|c|c|c|c|c|}
\hline Study site & $\begin{array}{l}\text { Total } \\
\text { area } \\
\left(\mathrm{m}^{2}\right)\end{array}$ & $\begin{array}{l}\text { Area of bare } \\
\text { ground }\left(\mathrm{m}^{2}\right)\end{array}$ & $\begin{array}{l}\text { Proportion of } \\
\text { sand material }(\%)\end{array}$ & $\begin{array}{l}\text { Vegetation } \\
\text { cover }(\%)\end{array}$ & $\begin{array}{l}\text { Tree } \\
\text { cover } \\
(\%)\end{array}$ & $\begin{array}{l}\text { Edge habitat } \\
(1 / 0.5 / 0)^{\mathrm{a}}\end{array}$ \\
\hline 1 Vånsjöbro $\mathrm{V}$ & 200 & 160 & 0 & 20 & 5 & 0.5 \\
\hline 2 Vånsjöbro Ö & 1,500 & 1,350 & 100 & 10 & 0 & 1 \\
\hline 3 Lugnet & 2,000 & 1,600 & 65 & 20 & 10 & 1 \\
\hline 4 Nyboda & 2,050 & 1,230 & 15 & 40 & 10 & 1 \\
\hline 5 Vallsgärde & 2,300 & 920 & 50 & 60 & 20 & 0 \\
\hline 6 Mehedeby & 3,600 & 3,240 & 100 & 10 & 20 & 1 \\
\hline 7 Östanås & 5,000 & 4,500 & 15 & 10 & 15 & 1 \\
\hline 8 Aspnäs & 6,600 & 3,300 & 100 & 50 & 30 & 0.5 \\
\hline 9 Nyåker & 7,000 & 6,650 & 100 & 5 & 40 & 0 \\
\hline 10 Vappeby & 50,000 & 45,000 & 5 & 10 & 15 & 0 \\
\hline 11 Svedjan & 74,000 & 70,300 & 5 & 5 & 65 & 1 \\
\hline 12 Korsbacken & 95,000 & 90,250 & 70 & 5 & 5 & 0.5 \\
\hline 13 Skommarbo & 180,000 & 171,000 & 5 & 5 & 5 & 1 \\
\hline
\end{tabular}

\footnotetext{
${ }^{a}$ Refers to the amount of forest surrounding the sand pit; 1 - surrounded by forest, 0.5 - surrounded partly
} by forest and partly by open area, 0 - surrounded by open area 
measure of sand pit size were calculated using this estimate; area of bare ground, where only the area not covered by vegetation were included (i.e., total area-[total area $\times$ vegetation cover]). Proportion of sand material estimated as the proportion of the area of bare ground where sand (grain size $0.2-2 \mathrm{~mm}$ ) is the dominant material. The remaining area of bare ground thus consists of material being defined as gravel $(>2 \mathrm{~mm})$. Tree cover was estimated as the proportion of the total area covered by tree crowns as seen from above, including trees $>0.5 \mathrm{~m}$. The edge habitat variable characterize the areas surrounding each study site into three categories: totally surrounded by forest (1), partly surrounded by forest (0.5) and not surrounded by forest (0). If not surrounded by forest, the surrounding consisted of open area, mainly arable land. Characteristics of each study site are listed in Table 1.

Beetle sampling

Beetles were sampled using pitfall traps (mouth diameter, $8.3 \mathrm{~cm}$; depth, $9.5 \mathrm{~cm}$ ) which were half-filled with a 50\% propylene glycol solution. Roofs were placed a few $\mathrm{cm}$ above the traps for protection from rain and larger animals. At each study site, five or six pitfall traps were used (72 in total). Six traps were placed at sites where there were relatively high risks of their destruction by human activity. The traps were placed on bare ground, with a high sand content and high sun exposure. They were placed no closer than two meters apart and away from edges where possible. The sampling period lasted from mid-April until mid-August 2008. During the sampling period, the traps were emptied and checked three times and disturbed traps were adjusted or replaced. An average of $7-18 \%$ of the traps were destroyed or removed between sampling intervals. As a result the sampling intensity varied between 756 and 442 trap days per site.

All beetles were identified to species-level by the authors (carabids) and by Gunnar Sjödin, following Lundberg (1995), with an adjustment for one new species. Literature used for the identification of carabids was Lindroth (1961), for Staphylinids Palm (1948-1972) and for other families mainly Danmarks Fauna (e.g., Hansen and Larsson 1965) and Die Käfer Mitteleuropas (Freude et al. 1965-1994). However, due to an initial mistake in the sorting, only a subset of the staphylinids was collected in about 32 traps situated in ten of the study sites during the first sampling period (mid-April to late-May). Because always a subset was collected and that only one part of the sampling period was affected we believe this mistake mainly affects the species abundance and less so species numbers. A further five specimens were too damaged to be identified and were excluded. All species were classified into three habitat-preference categories: sand-dwelling, open ground-dwelling and forest-dwelling, based on information from Hansen (1964), Koch (1989-1992), Lindroth (1961) and Palm (1948-1972). A few species did not fit into any of the three categories and were classified as 'indifferent'. The categories sand-dwelling and forest-dwelling included species specialized for living, or mainly living, in the respective habitats, whereas open ground-dwelling species also included generalists and species occurring in other habitats. The species in each category are hereafter referred to as 'sand species', 'open ground species' and 'forest species'. Red-listed species were defined after Gärdenfors (2010).

\section{Data analysis}

For each site, the beetle data collected were pooled. All species data were included in the analysis, despite some differences in sampling intensity. To handle these differences, 
sampling intensity, calculated as the number of trap days per site, was included in all regression models and in the ordinations as a covariable.

The SAR was tested using two models: the commonly used log-log power function, $S=c A^{Z}$ (Arrhenius 1921; Tjørve 2003), and a curved model called the quadratic power function, $S=10^{(b 0+b 1 \log A+b 2(\log A) 2)}$ (Chiarucci et al. 2006), where $S=$ species number, $A=$ area, $z=$ the slope ( $z$ value) and $c$ and $b_{x}$ are constants. The models were chosen to fit our empirical data and according to Dengler (2009) both models generally perform well. The species numbers were $\log _{10}(n+1)$ transformed since they included zero-values. The area variables were $\log _{10}$-transformed in accordance with the models. Two measures representing the size of the sand pit (total area and area of bare ground) were tested parallel to see their relative ability in predicting species number. The $z$ values were calculated without sampling intensity as a covariable.

Linear regressions were performed to analyze the effects of the measured environmental variables on the numbers and proportions of all beetle species and carabid species, respectively. The variables were tested both individually and in multiple regressions by stepwise regression (combining both forward selection and backwards elimination) to identify significant variables $(p<0.05)$. For the multiple regressions, the covariable sampling intensity was added afterwards when the significant subset of variables had been identified. The adjusted $R^{2}$ values were used throughout, so that the number of explanatory variables included would not influence the goodness of fit. For carabids, the data from the study site Nyboda were not included in the regressions that included the proportion of species, as the low total number of species (two) gave a misleading value (and an outlier) for the proportion of sand species (100\%). The statistical software Minitab 15 was used for all the regressions.

Species composition was analyzed using correspondence analysis (CA) and the effects of the environmental variables on species composition were analyzed by canonical correspondence analysis (CCA) (Leps and Smilauer 2003). Species occurring at only one site were excluded, and the species data were square root-transformed to reduce the effects of dominant species (Leps and Smilauer 2003). The significance of the environmental variables was tested with a Monte Carlo permutation test (499 permutations). Sampling intensity was included as a covariable and values of 'percents variance explained' and 'eigenvalues' were taken after fitting the covariable. Two different combinations of species assemblages were tested: all beetles $(n=108)$ and only carabids $(n=25)$. Canoco for Windows 4.5 was used for the ordination (Braak and Smilauer 1998).

\section{Results}

A total of almost 2,500 beetles were sampled, representing 256 species of 30 families (see species list in Appendix Table 4). Sand species were relatively abundant (42\%), but were represented by only 39 species $(15 \%)$, half of which belonged to the carabid family (20 species). The most numerous species was the sand-dwelling carabid Lionychus quadrillum $(n=395)$, followed by two other sand species, Anthicus flavipes $(n=176)$ and Calathus erratus $(n=166)$. Half of the species $(n=126)$ were only represented by one individual. Two species (Apalus bimaculatus and Lycoperdina succincta) are listed as 'near threatened' in the 2010 Swedish Red List (Gärdenfors 2010).

Per study site, the number of species of all beetles ranged from 20 to 67 and the number of individuals from 59 to 444. The number of sand species ranged between 2 and 15, and the proportion of sand species between 3 and $30 \%$. The corresponding numbers per study 
site for carabids were $2-14$ species, $18-165$ individuals, $0-8$ sand species and $0-100 \%$ sand species.

Carabids were the most abundant beetle family with 901 individuals of 58 species. They represent one-fourth of the total number of species and half of the sand species. As carabids account for a substantial part of the total beetle species number it is expected for species numbers of these two groups to be correlated $\left(p=0.009, R^{2}=69.3 \%\right.$ for all species; $p=0.001, R^{2}=81.1 \%$ for sand species).

\section{Species-area relationships}

The area of bare ground were chosen to represent the area of the sand pit as it gave a slightly better fit than the highly correlated $(0.992, p=0.000)$ variable total area (Table 2). A positive SAR was found for sand-dwelling species, both for carabids and for all beetles, respectively (Table 2; Fig. 2). The quadratic power function gave the best fit, whereas the power function showed a near-significant relationship with $z$ values of 0.25 for sand-dwelling carabids and 0.12 for sand-dwelling beetles (Table 2).

When including beetles from all habitat categories, no SAR could be seen, neither for carabids nor for all beetle families (Table 2).

\section{Species composition}

In the CCA including all beetles, the species composition was best explained by the area of bare ground (Table 3). This can also be visualised in the CA-biplot (Fig. 3a) where the small sand pits are separated from the larger ones along the first axis. Also, the sand species tend to be situated more to the right of the first axis together with the large and mediumsized sand pits (Fig. 3a). In the CA (with environmental variables included through an indirect gradient analysis) the three first axes explained $53.5 \%$ of the variance in the species-environmental data (five variables included) and $43.3 \%$ of the variance in the species data (total inertia 2.130; eigenvalues $0.338,0.284$, and 0.231 for axes one, two and three).

Table 2 Species-area relationship

\begin{tabular}{|c|c|c|c|c|c|c|c|}
\hline \multirow[t]{2}{*}{ Area variable } & \multirow[t]{2}{*}{$\begin{array}{l}\text { Systematic } \\
\text { gr. }\end{array}$} & \multirow[t]{2}{*}{ Habitat group } & \multicolumn{3}{|c|}{ Power function } & \multicolumn{2}{|c|}{$\begin{array}{l}\text { Quadratic power } \\
\text { function }\end{array}$} \\
\hline & & & $p$ & $R^{2}$ & $z$ & $p$ & $R^{2}$ \\
\hline Bare ground & Beetles & No. of sand species & $0.074^{(*)}$ & 28.7 & 0.12 & $0.029 *$ & 48.5 \\
\hline Total area & Beetles & No. of sand species & $0.076^{(*)}$ & 28.2 & 0.13 & $0.046^{*}$ & 43.0 \\
\hline Bare ground & Carabids & No. of sand species & $0.046^{*}$ & 35.3 & 0.25 & $0.011^{*}$ & 59.4 \\
\hline Total area & Carabids & No. of sand species & $0.066^{(*)}$ & 30.3 & 0.25 & $0.046^{*}$ & 42.9 \\
\hline Bare ground & Beetles & Total species number & 0.603 & 0.0 & & 0.768 & 0.0 \\
\hline Total area & Beetles & Total species number & 0.544 & 0.0 & & 0.742 & 0.0 \\
\hline Bare ground & Carabids & Total species number & 0.653 & 0.0 & & 0.637 & 0.0 \\
\hline Total area & Carabids & Total species number & 0.714 & 0.0 & & 0.751 & 0.0 \\
\hline
\end{tabular}

$R^{2}$ and $p$ values for regressions of area (total area and area of bare ground) against species number (total species number and number of sand species) for beetles and carabids, described with a $\log -\log$ power function, $S=c A^{Z}$, and a quadratic power function, $S=10^{(b 0+b 1 \log A+b 2(\log A) 2)}$

Significance levels: $\left.* p<0.05 ;{ }^{*}\right) p<0.1$ 

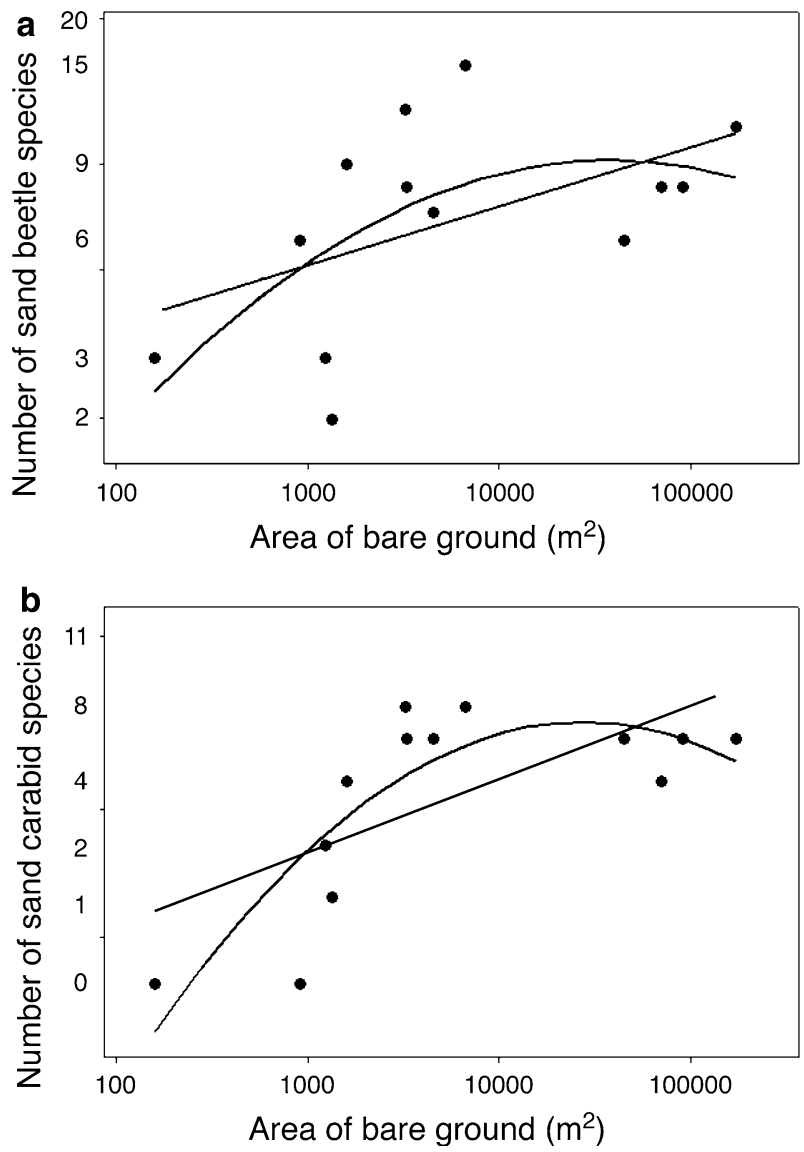

Fig. 2 The species-area relationship, described with a power function (straight lines) and quadratic power function (curved lines), $\mathbf{a}$ for all sand-dwelling beetles, $\mathbf{b}$ for sand-dwelling carabids. Summary statistics are shown in Table 2

In the CCA including solely the carabid data both area of bare ground and proportion of sand material significantly explained species composition (Table 3). As for all beetles, the CA-biplot for carabids showed the small pits mainly to the left in the diagram and sand species to the right (Fig. 3b). The CA's first three axes explained $71.7 \%$ of the variance in the speciesenvironmental data (five variables included) and $64.1 \%$ of the variance in the species data (total inertia 1.972; eigenvalues $0.558,0.406$, and 0.245 for axes one, two and three).

\section{Effect of environmental variables}

The proportion of sand material was positively related to species number when all beetle species were considered $\left(p=0.024, R^{2}=30.6 \%\right)$. None of the other environmental variables could individually explain species number significantly. Of the multiple regressions the only significant relationship we found was the one for numbers of forest species where the proportion of sand material (positively) and edge habitat (positively by forest) together had an influence $\left(R^{2}=51.8 \%, p=0.022\right)$. 
Table 3 Environmental variables fitted in a stepwise manner by forward selection in a CCA model

\begin{tabular}{lllll}
\hline Systematic group & Explanatory variable & Variance explained (\%) & $p$ & $F$ \\
\hline Beetles & Area of bare ground & 27.7 & $0.012^{*}$ & 1.56 \\
& Proportion of sand material & 20.9 & 0.210 & 1.20 \\
& Tree cover & 19.0 & 0.334 & 1.11 \\
& Edge habitat & 18.9 & 0.366 & 1.12 \\
& Vegetation cover & 13.4 & 0.702 & 0.77 \\
Carabids & Area of bare ground & 35.2 & $0.004^{*}$ & 2.51 \\
& Proportion of sand material & 25.8 & $0.028^{*}$ & 2.02 \\
& Tree cover & 15.1 & 0.266 & 1.21 \\
& Edge habitat & 14.0 & 0.350 & 1.15 \\
& Vegetation cover & 10.0 & 0.570 & 0.79 \\
\hline
\end{tabular}

The significance of each variable was tested with a Monte Carlo permutation test (499 permutations). Variance explained is the percentage explained by each variable of the total variance explained by all five variables

Significance level: ${ }^{*} p<0.05$

The type of edge habitat was related to the proportion of species associated with certain habitats. The proportion of forest species was positively influenced by the amount of forest surrounding the sand pit $\left(p=0.018, R^{2}=54.5 \%\right)$ and the proportion open ground species was negatively influenced $\left(p=0.018, R^{2}=33.3 \%\right)$ whereas there were no influence found on proportion sand species. Proportion sand species was positively influenced by tree cover $\left(p=0.019, R^{2}=45.5 \%\right)$. These relationships could not be seen when only analysing carabid species.

\section{Discussion}

Species-area relationships

We found a positive species area relationship (SAR) for sand-dwelling beetles in sand pit habitats. This is consistent with island biogeography theory (MacArthur and Wilson 1967) and previous SAR studies including beetles (e.g., Lövei et al. 2006; Magura et al. 2001; Vries de et al. 1996). The SAR model that best explained the relationship was the quadratic power function (Chiarucci et al. 2006; Dengler 2009), where the fitted SA-curve shows a rapid initial increase in the number of sand species followed by a peak at around 2.5-3 ha and then a decrease (Fig. 3). As we lack study sites with areas around 2.5-3 ha we cannot conclude this to be the optimum size of a sand pit for harbouring a high number of sand species. However, we can conclude that the four large sand pits (5-18 ha) on average do not harbour more sand species than does the four medium-sized pits $(0.36-0.7 \mathrm{ha})$. This is true both for all beetles (mean $\pm \mathrm{SD}$ for sand species: large $8.3 \pm 2.1$, medium $10.5 \pm 3.7$ ) and for carabids (mean $\pm \mathrm{SD}$ for sand species: large $5.5 \pm 1.0$, medium $7.0 \pm 1.2$ ). How this finding should be applied into practical conservation is further discussed under the last section 'Practical implication'.

From our field observations of the study sites we noticed a distinguishable difference of the four largest sand pits from the smaller ones. The large sand pits could all be described as more homogenous in terms of topology and vegetation; with large plane areas, steep 

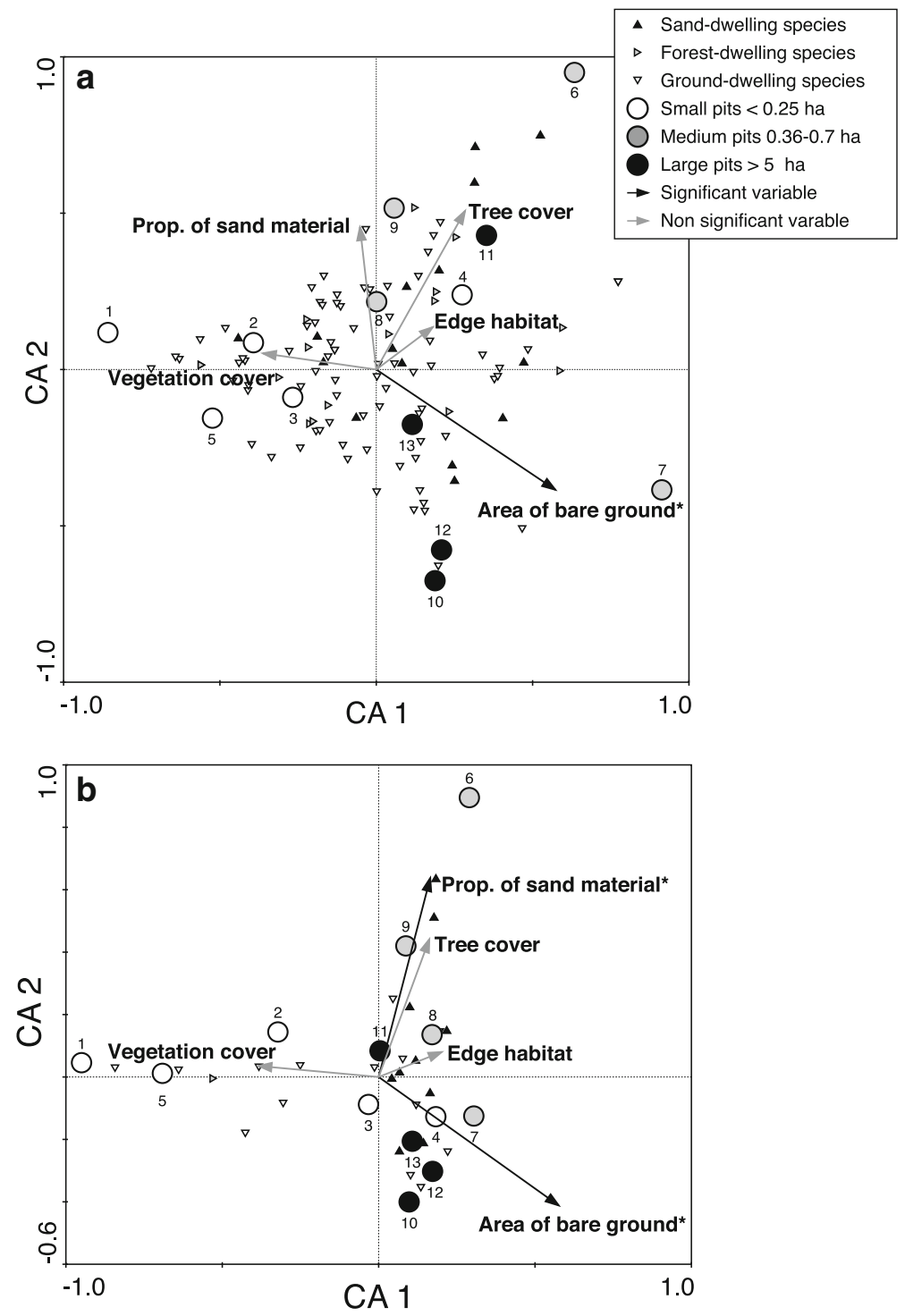

Fig. 3 A correspondence analysis (CA) biplot of species composition of $\mathbf{a}$ beetles and $\mathbf{b}$ carabids, showing axes 1 and 2. Environmental variables are included through an indirect gradient analysis. Their significance in explaining the variance in species composition was assessed in a CCA, and significant variables are marked with an asterisk (*) and shown in black (non-significant variables are shown in gray). The circles represent the thirteen study sites divided into three categories according to size; numbered as in Table 2 . Triangles represent the species divided into three habitat-preference categories

edges and either even-aged young trees or almost no vegetation at all. We believe this difference between sites could explain why no more sand species were found in large sand pits compared to medium-sized ones. Of the two prominent hypotheses for SAR this observation would give more support to the 'habitat heterogeneity hypothesis' than the 
'area per se hypothesis' (Báldi 2008). However, the strong interactions between the features that the two hypotheses are based upon make drawing clear conclusion difficult without further direct studies (Connor and McCoy 1979; Kallimanis et al. 2008).

The rate of increase in species number with area were illustrated by the $\log -\log$ SAcurves of the power function (Fig. 2) and showed a more rapid increase in species number for carabids $(z=0.25)$ than for all beetles $(z=0.12)$. According to Connor and McCoy (1979), $z$ values regularly fall between 0.20 and 0.40 , and according to a review by Drakare et al. (2006), the average $z$ value obtained in investigations using independent sampling schemes (among 794 SAR studies considered) was 0.24 . Whether the $\mathrm{z}$ value has any further biological significance has been debated, often with scepticism (Connor and McCoy 1979; He and Legender 1996; Martin 1981). However, Drakare et al. (2006) detected apparent systematic correlations between $z$ values and latitude (negative), organism size (negative; explained by the higher dispersal ability of small organisms) and habitat (lower in non-forested habitats). As this study examined relationships of small organisms dwelling in non-forested habitats at high latitude we should expect low $z$ values, which was true for beetles (0.12), but not for carabids (for which the value was close to the average cited above; 0.25$)$.

\section{Influence of the surrounding matrix}

In contrast to the sand species, no SAR was found when all species (irrespective of habitatpreferences) were included in the analysis. The same pattern has been observed for other terrestrial habitat islands, in which positive SARs have only been found for the habitatspecific species (Lövei et al. 2006; Magura et al. 2001; Vries de et al. 1996). This can be explained by an influence of the surrounding matrix where matrix species invade the habitat island resulting in an increase of species richness along the edges (Cook et al. 2002; Ewers and Didham 2006; Magura 2002; Niemelä 2001). This edge effect then counteracts the area effect because of the greater edge:area ratio in smaller patches (Lövei et al. 2006; Vries de 1994), which can make edge and area effects difficult to distinguish (Ewers et al. 2007; Fletcher et al. 2007). By only including species specialized to the habitat studied, the habitat island will more likely resemble an actual island and hence better follow island biogeography theory (MacArthur and Wilson 1967). Our findings strengthen the notion that only species specialized to the habitat studied should be included when applying SAR in terrestrial habitat patches.

Our notion that sand pits are influenced by species from the surrounding matrix is further strengthened as the species assemblages in the sand pits were related to the surrounding edge habitat. When surrounded by forests there was a higher proportion of forest species in the patches, and when surrounded by open areas the proportion of open ground species was higher. For the proportion of sand species there was no relationship with the type of edge habitat. These patterns combined strongly suggest that there are edge effects mainly affecting our small sand pits $(0.02-0.23 \mathrm{ha})$.

\section{Species composition}

The area of the sand pit was the major factor influencing species composition. The main difference in species composition was between small sand pits and medium/large ones where most sand species were associated with the medium/large sand pits (Fig. 3). 
The composition of carabids was in addition influenced by the proportion of sand material. This variable differentiates between the coarseness of the ground material (either sand or gravel) hence some species seem to have preference for one or the other soil type.

\section{Effect of environmental variables}

The proportion of sand material had a positive influence on species number of all beetles, whereas the influence was not significant for sand species. Also, the number of forest species increased with an increase in proportion of sand material (when the type of edge habitat was accounted for). We would have expected a connection between sand species and proportion of sand material but why total species number and forest species would be affected is puzzling to us and thus we keep from speculation about its reasons.

The proportion of sand species was positively influenced by tree cover. The influence of tree cover is puzzling and we can only speculate of its function. It might work as a wind shelter improving the microclimate or it could be due to that boreal sand species have evolved to use habitats produced by ground fires in forests, where a lot of trees are retained.

\section{Carabids as indicators}

The value of carabids as indicators of total beetle species diversity in sand pits lies almost solely in their high representation among the sampled species. The analyses including all beetles gave similar results to those including only carabids for the SAR and species composition (CCA), but not for the other environmental variables tested. Thus, we cannot fully support carabids as useful indicators of other beetles in sand pits. However, the advantages of choosing carabids as a study group in sand pits is that they are easy to sample and identify and have high representation with respect to species number; therefore they are a major component of the assemblages that require conservation.

\section{Rare species in sand pits}

Only two red-listed species were found in the study. This may seem surprising as several studies have found higher frequencies of red-listed species in sand pits (Bergsten 2007; Eversham et al. 1996; Frycklund 2003; Ljungberg 2002; Schiel and Rademacher 2008; Sörensson 2006). One explanation for the low number of detected red-listed species is that they might simply have been missed in the sampling because they are too rare (Martikainen and Kouki 2003). In addition, most of the Swedish red-listed species that are associated with early successional habitats have a southern distribution in the country. Some of the species we found would probably deserve red-listing at a regional scale (e.g., Cymindis angularis and Melanimon tibiale), but they are too frequent in the southern part of the country to be nationally red-listed. At Marma shooting range, a site dominated by disturbed sand habitats and situated close to the northernmost of our study sites, three red-listed sand species were previously found (Eriksson et al. 2005), none of which were detected in this study. It is difficult to tell if this difference is due to some specific habitat requirements being fulfilled at the Marma site, or if it is a coincidence because of their rarity. However, almost half of the species encountered in our study were only represented by one individual, indicating that more species are present at our study sites, in addition to those we detected. 
Practical implications

When conserving sand pit habitats for sand-dwelling beetles it is important not to choose sites with too small area. According to this study the cut-off area lies somewhere around 0.3 ha. The reason for this recommendation is because smaller sand pits harbour fewer species and because they are too strongly affected by species from the surrounding habitats, which displace the target species. Besides this recommendation we cannot give an optimum area for conserving a high number of sand species. However, as the largest sand pits ( $>5$ ha) do not host more sand species than the medium-sized ones ( $0.36-0.7$ ha), we would recommend to prioritized sand pit of intermediate size simply because of the economical advantage of preserving a smaller area. To specify a number, this would limit the recommended area range to $0.3-5$ ha with preference towards the low end of this range.

Another reason not to prioritize large sand pits for conservation is that we believe there is a general pattern of homogeneity of larger sand pits due to difference in management compared to smaller sand pits. Large sand pit are often run with more modern and heavier machinery which thus make them more uniform. This however should be properly tested to be able to make inferences about how heterogeneity of sand pits affect species number and composition.

The recommended areas mentioned above are estimates of the sand pits total area, including parts with vegetation cover. However, the area of a sand pit could also be estimated by only including the area of bare ground, as used in this study because it made a slightly better predictor of species number. This indicates the importance of this feature for sand-dwelling beetles. On the contrary, the area of bare ground might not be adequate to predict species richness of other species groups because they require other features besides the bare ground of sand or gravel. For example, the many aculeate wasps that use bare sand to dig nests also require a nearby nectar resource (Bergsten 2007; Sörensson 2006) and a diverse flora is more likely to support specific host plants required for many butterflies (Frycklund 2003). To conclude, even though area of bare ground has been shown to give the best predictions for beetles, we believe total area of sand pits overall is best to consider for conservation of sand pit habitats. This is because it gives a good prediction for beetle species number, it is easy to measure (even from aerial photos) and it includes the vegetation feature impotent to several other species groups.

In the Swedish sand mining industry the trend is to work fewer but larger sand pits (953 licensed pits in 2008) And the overall extraction of sand and gravel from natural deposits is decreasing, from 29.3 Mt in 1998 to $18.8 \mathrm{Mt}$ in 2008 (Anon. 2009). The goal set by the government is to further decrease the extraction and meet demands for sand material with crushed bedrock from stone quarries. With decreasing extraction, more sand pits will be abandoned in the near future. Instead of following up sand pit abandonment with costly restoration, which inevitably destroys the sand habitat, the opportunity should be taken to preserve these valuable open sand habitats.

Acknowledgments The authors are grateful to Gunnar Sjödin for identifying the non-carabid beetles and to Håkan Ljungberg who helped identifying some critical carabids. The authors also thank Erik Sjödin, who helped us with damaged traps in the field, and to the County Administration of Uppsala, who provided data on potential field sites. The authors also acknowledge the help of Riccardo Bommarco, Ann Kristin Eriksson and two anonymous reviewers for comments and discussions on earlier versions of this manuscript. Financial support was provided by FORMAS (to MJ), the Department of Ecology, SLU and the Entomological Society in Uppland. 
Open Access This article is distributed under the terms of the Creative Commons Attribution License which permits any use, distribution, and reproduction in any medium, provided the original author(s) and the source are credited.

\section{Appendix}

See Table 4.

Table 4 A species list including all species encountered in the study, in systematic order according to Lundberg (1995), including the classification of habitat categories used

\begin{tabular}{|c|c|c|c|}
\hline Species & Habitat category & Number of sites & Abundance \\
\hline Leistus terminatus* & Forest & 1 & 1 \\
\hline Leistus ferrugineus* & Ground & 3 & 3 \\
\hline Nebria brevicollis* & Forest & 1 & 1 \\
\hline Notiophilus aestuans* & Sand & 1 & 1 \\
\hline Notiophilus palustris* & Forest & 1 & 2 \\
\hline Notiophilus germinyi* & Ground & 2 & 5 \\
\hline Notiophilus biguttatus* & Forest & 1 & 4 \\
\hline Loricera pilicornis* & Forest & 1 & 1 \\
\hline Carabus granulatus* & Ground & 2 & 2 \\
\hline Carabus nemoralis* & Ground & 1 & 3 \\
\hline Carabus hortensis* & Forest & 1 & 1 \\
\hline Carabus coriaceus* & Forest & 1 & 1 \\
\hline Cicindela campestris* & Ground & 3 & 6 \\
\hline Clivina fossor* & Ground & 2 & 4 \\
\hline Dyschirius politus* & Sand & 2 & 5 \\
\hline Broscus cephalotes* & Sand & 5 & 77 \\
\hline Trechus secalis* & Ground & 3 & 5 \\
\hline Trechus quadristriatus* & Sand & 2 & 5 \\
\hline Asaphidion pallipes* & Sand & 1 & 1 \\
\hline Asaphidion flavipes* & Ground & 1 & 1 \\
\hline Bembidion lampros* & Ground & 8 & 16 \\
\hline Bembidion obtusum* & Ground & 1 & 1 \\
\hline Bembidion femoratum* & Sand & 1 & 1 \\
\hline Bembidion quadrimaculatum* & Sand & 2 & 4 \\
\hline Bembidion guttula* & Ground & 2 & 3 \\
\hline Stomis pumicatus* & Ground & 2 & 2 \\
\hline Pterostichus lepidus* & Sand & 4 & 5 \\
\hline Pterostichus cupreus* & Ground & 2 & 2 \\
\hline Pterostichus versicolor* & Ground & 1 & 1 \\
\hline Pterostichus oblongopunctatus* & Forest & 1 & 6 \\
\hline Pterostichus niger* & Forest & 5 & 18 \\
\hline Pterostichus melanarius* & Ground & 4 & 23 \\
\hline Pterostichus gracilis* & Ground & 1 & 1 \\
\hline
\end{tabular}


Table 4 continued

\begin{tabular}{|c|c|c|c|}
\hline Species & Habitat category & Number of sites & Abundance \\
\hline Pterostichus strenuи * & Forest & 1 & 1 \\
\hline Calathus erratus* & Sand & 11 & 166 \\
\hline Anchomenus dorsalis* & Ground & 1 & 1 \\
\hline Amara communis* & Ground & 1 & 1 \\
\hline Amara eurynota* & Ground & 1 & 1 \\
\hline Amara familiaris* & Ground & 1 & 1 \\
\hline Amara cursitans* & Sand & 1 & 2 \\
\hline Amara quenseli* & Sand & 7 & 40 \\
\hline Amara bifrons* & Sand & 1 & 1 \\
\hline Amara praetermissa* & Ground & 2 & 2 \\
\hline Amara fulva* & Sand & 4 & 6 \\
\hline Amara consularis* & Sand & 3 & 3 \\
\hline Amara equestris* & Sand & 1 & 1 \\
\hline Badister bullatus* & Ground & 1 & 1 \\
\hline Harpalus rufipes* & Ground & 8 & 54 \\
\hline Harpalus affinis* & Ground & 3 & 4 \\
\hline Harpalus distinguendus* & Sand & 1 & 2 \\
\hline Harpalus smaragdinus* & Sand & 1 & 1 \\
\hline Harpalus quadripunctatus* & Forest & 1 & 1 \\
\hline Harpalus rubripes* & Sand & 1 & 1 \\
\hline Harpalus tardus* & Ground & 1 & 1 \\
\hline Acupalpus meridianus* & Ground & 1 & 1 \\
\hline Dromius sigma* & Ground & 1 & 1 \\
\hline Lionychus quadrillum* & Sand & 7 & 395 \\
\hline Cymindis angularis* & Sand & 1 & 1 \\
\hline Agabus subtilis & Indiff. & 1 & 1 \\
\hline Helophorus brevipalpis & Indiff. & 1 & 1 \\
\hline Stenichnus scutellaris & Forest & 3 & 5 \\
\hline Stenichnus collaris & Forest & 3 & 5 \\
\hline Silpha tristis & Ground & 1 & 1 \\
\hline Phosphuga atrata & Forest & 1 & 1 \\
\hline Gabrius osseticus & Forest & 1 & 1 \\
\hline Philonthus carbonarius & Indiff. & 1 & 1 \\
\hline Platydracus fulvipes & Forest & 2 & 2 \\
\hline Staphylinus caesareus & Ground & 1 & 1 \\
\hline Ocypus ophthalmicus & Sand & 1 & 1 \\
\hline Ocypus nero & Forest & 4 & 6 \\
\hline Ocypus melanarius & Ground & 1 & 1 \\
\hline Quedius maurus & Forest & 2 & 2 \\
\hline Quedius molochinus & Ground & 2 & 2 \\
\hline Quedius boops & Indiff. & 1 & 1 \\
\hline Gyrohypnus scoticus & Ground & 1 & 4 \\
\hline Xantholinus linearis & Ground & 1 & 4 \\
\hline
\end{tabular}


Table 4 continued

\begin{tabular}{|c|c|c|c|}
\hline Species & Habitat category & Number of sites & Abundance \\
\hline Xantholinus audrasi & Ground & 1 & 1 \\
\hline Xantholinus tricolor & Ground & 4 & 24 \\
\hline Othius punctulatus & Forest & 1 & 1 \\
\hline Othius myrmecophilus & Indiff. & 1 & 1 \\
\hline Astenus longelytratu & Ground & 1 & 1 \\
\hline Rugilus rufipes & Indiff. & 1 & 2 \\
\hline Scopaeus cognatus & Sand & 1 & 1 \\
\hline Lathrobium volgense & Ground & 4 & 4 \\
\hline Lathrobium fulvipenne & Ground & 1 & 3 \\
\hline Lathrobium brunnipes & Ground & 1 & 1 \\
\hline Lathrobium longulum & Ground & 1 & 2 \\
\hline Lathrobium pallidum & Ground & 1 & 1 \\
\hline Stenus biguttatus & Sand & 1 & 3 \\
\hline Stenus clavicornis & Ground & 2 & 2 \\
\hline Stenus geniculatus & Forest & 1 & 1 \\
\hline Brachygluta fossulata & Ground & 5 & 51 \\
\hline Pselaphus heisei & Ground & 1 & 1 \\
\hline Deliphrum tectum & Indiff. & 1 & 1 \\
\hline Anthobium atrocephalum & Forest & 3 & 4 \\
\hline Olophrum assimile & Forest & 1 & 3 \\
\hline Arpedium quadrum & Ground & 3 & 8 \\
\hline Anotylus rugosus & Indiff. & 6 & 7 \\
\hline Bledius opacus & Sand & 1 & 1 \\
\hline Bledius fergussoni & Sand & 6 & 23 \\
\hline Trichophya pilicornis & Forest & 5 & 10 \\
\hline Mycetoporus lepidus & Ground & 1 & 1 \\
\hline Mycetoporus longulus & Ground & 2 & 4 \\
\hline Mycetoporus forticornis & Ground & 1 & 1 \\
\hline Bolitobius cingulatus & Forest & 1 & 1 \\
\hline Bolitobius castaneus & Forest & 1 & 2 \\
\hline Sepedophilus pedicularius & Ground & 2 & 3 \\
\hline Tachyporus nitidulus & Ground & 4 & 4 \\
\hline Tachyporus hypnorum & Ground & 3 & 3 \\
\hline Tachyporus chrysomelinus & Ground & 1 & 1 \\
\hline Tachyporus corpulentus & Forest & 1 & 1 \\
\hline Tachinus rufipes & Ground & 3 & 7 \\
\hline Tachinus laticollis & Ground & 1 & 1 \\
\hline Aleochara bipustulata & Ground & 9 & 25 \\
\hline Oxypoda umbrata & Forest & 2 & 2 \\
\hline Oxypoda vicina & Sand & 1 & 1 \\
\hline Oxypoda annularis & Indiff. & 2 & 2 \\
\hline Thiasophila angulata & Ground & 2 & 2 \\
\hline Ilyobates subopacus & Ground & 3 & 3 \\
\hline
\end{tabular}


Table 4 continued

\begin{tabular}{|c|c|c|c|}
\hline Species & Habitat category & Number of sites & Abundance \\
\hline Dinarda dentata & Ground & 1 & 1 \\
\hline Aloconota planifrons & Ground & 1 & 1 \\
\hline Aloconota gregaria & Ground & 12 & 103 \\
\hline Geostiba circellaris & Ground & 1 & 1 \\
\hline Callicerus obscurus & Ground & 1 & 1 \\
\hline Philhygra britteni & Ground & 1 & 1 \\
\hline Atheta (Xenota) myrmecobia & Forest & 1 & 1 \\
\hline Atheta (Alaobia) scapularis & Forest & 3 & 3 \\
\hline Atheta (Alaobia) gagatina & Indiff. & 2 & 4 \\
\hline Atheta s. str. oblita & Indiff. & 1 & 1 \\
\hline Atheta s. str. harwoodi & Indiff. & 1 & 1 \\
\hline Dinaraea angustula & Ground & 1 & 1 \\
\hline Amischa nigrofusca & Ground & 5 & 20 \\
\hline Amischa analis & Ground & 6 & 9 \\
\hline Amischa bifoveolata & Ground & 12 & 126 \\
\hline Anaulacaspis nigra & Sand & 9 & 75 \\
\hline Drusilla canaliculata & Ground & 5 & 21 \\
\hline Zyras limbatus & Ground & 1 & 1 \\
\hline Lomechusa emarginata & Ground & 2 & 2 \\
\hline Cyphon padi & Ground & 1 & 1 \\
\hline Geotrupes stercorosus & Forest & 2 & 7 \\
\hline Serica brunnea & Ground & 1 & 2 \\
\hline Amphimallon solstitiale & Ground & 1 & 1 \\
\hline Cetonia aurata & Ground & 11 & 58 \\
\hline Phosphaenus hemipterus & Ground & 1 & 1 \\
\hline Cantharis obscura & Ground & 1 & 1 \\
\hline Cantharis pellucida & Ground & 1 & 1 \\
\hline Cantharis livida & Ground & 1 & 1 \\
\hline Rhagonycha lignosa & Ground & 1 & 1 \\
\hline Athous hirtus & Ground & 1 & 1 \\
\hline Limonius aeneoniger & Ground & 3 & 4 \\
\hline Prosternon tessellatum & Ground & 1 & 1 \\
\hline Anostirus castaneus & Ground & 1 & 1 \\
\hline Selatosomus aeneus & Ground & 3 & 4 \\
\hline Sericus brunneus & Ground & 1 & 1 \\
\hline Agriotes sputator & Ground & 1 & 1 \\
\hline Dalopius marginatus & Forest & 2 & 2 \\
\hline Trixagus dermestoides & Forest & 2 & 4 \\
\hline Trixagus carinifrons & Forest & 1 & 1 \\
\hline Morychus aeneus & Sand & 1 & 2 \\
\hline Byrrhus pustulatus & Sand & 4 & 5 \\
\hline Hadrobregmus pertinax & Ground & 1 & 1 \\
\hline Kateretes pusillus & Ground & 1 & 1 \\
\hline
\end{tabular}


Table 4 continued

\begin{tabular}{|c|c|c|c|}
\hline Species & Habitat category & Number of sites & Abundance \\
\hline Carpophilus marginellus & Ground & 2 & 2 \\
\hline Epuraea aestiva & Ground & 1 & 1 \\
\hline Meligethes aeneus & Ground & 2 & 2 \\
\hline Meligethes tristis & Ground & 1 & 2 \\
\hline Thalycra fervida & Ground & 4 & 4 \\
\hline Glischrochilus hortensis & Ground & 1 & 1 \\
\hline Cryptophagus bimaculatus & Ground & 1 & 1 \\
\hline Atomaria rubella & Ground & 1 & 1 \\
\hline Atomaria atricapilla & Ground & 1 & 2 \\
\hline Atomaria nitidula & Ground & 1 & 2 \\
\hline Atomaria wollastoni & Ground & 4 & 6 \\
\hline Dacne bipustulata & Ground & 1 & 1 \\
\hline Lycoperdina succincta $(N T)$ & Sand & 1 & 1 \\
\hline Endomychus coccineus & Forest & 1 & 1 \\
\hline Exochomus quadripustulatus & Ground & 1 & 1 \\
\hline Propylea quatuordecimpunctata & Ground & 3 & 3 \\
\hline Halyzia sedecimguttata & Ground & 1 & 1 \\
\hline Coccinella septempunctata & Ground & 4 & 4 \\
\hline Coccinella quinquepunctata & Ground & 2 & 3 \\
\hline Enicmus rugosus & Ground & 1 & 1 \\
\hline Enicmus transversus & Ground & 1 & 2 \\
\hline Stephostethus lardarius & Ground & 1 & 1 \\
\hline Aridius nodifer & Ground & 2 & 2 \\
\hline Corticaria saginata & Ground & 1 & 1 \\
\hline Cortinicaria gibbosa & Ground & 3 & 3 \\
\hline Corticarina fuscula & Ground & 6 & 13 \\
\hline Orthocerus clavicornis & Sand & 1 & 1 \\
\hline Chrysanthia nigricornis & Ground & 2 & 2 \\
\hline Notoxus monoceros & Sand & 1 & 1 \\
\hline Anthicus flavipes & Sand & 6 & 176 \\
\hline Anthicus ater & Ground & 1 & 1 \\
\hline Apalus bimaculatus (NT) & Sand & 1 & 1 \\
\hline Opatrum sabulosum & Sand & 1 & 10 \\
\hline Melanimon tibiale & Sand & 2 & 7 \\
\hline Isomira murina & Sand & 1 & 1 \\
\hline Lagria hirta & Ground & 1 & 1 \\
\hline Mordella huetheri & Ground & 1 & 1 \\
\hline Mordellistena parvula & Sand & 1 & 1 \\
\hline Bromius obscurus & Ground & 1 & 1 \\
\hline Phyllotreta vittula & Ground & 10 & 94 \\
\hline Phyllotreta undulata & Ground & 4 & 5 \\
\hline Phyllotreta striolata & Ground & 6 & 13 \\
\hline Phyllotreta nigripes & Ground & 1 & 1 \\
\hline
\end{tabular}


Table 4 continued

\begin{tabular}{|c|c|c|c|}
\hline Species & Habitat category & Number of sites & Abundance \\
\hline Aphthona euphorbiae & Ground & 3 & 4 \\
\hline Longitarsus succineus & Ground & 2 & 2 \\
\hline Longitarsus melanocephalus & Ground & 1 & 1 \\
\hline Longitarsus suturellus & Ground & 3 & 4 \\
\hline Longitarsus nasturtii & Ground & 4 & 22 \\
\hline Altica palustris & Ground & 1 & 1 \\
\hline Chaetocnema concinna & Ground & 2 & 4 \\
\hline Chaetocnema laevicollis & Ground & 8 & 20 \\
\hline Chaetocnema hortensis & Ground & 10 & 29 \\
\hline Apion apricans & Ground & 2 & 4 \\
\hline Apion meieri & Ground & 3 & 4 \\
\hline Apion meliloti & Ground & 1 & 1 \\
\hline Apion virens & Ground & 1 & 1 \\
\hline Otiorhynchus raucus & Ground & 6 & 131 \\
\hline Otiorhynchus scaber & Forest & 1 & 1 \\
\hline Otiorhynchus desertus & Ground & 1 & 1 \\
\hline Otiorhynchus ovatus & Ground & 5 & 8 \\
\hline Trachyphloeus rectus & Sand & 1 & 2 \\
\hline Trachyphloeus bifoveolatus & Ground & 4 & 4 \\
\hline Phyllobius maculicornis & Ground & 1 & 1 \\
\hline Polydrusus pilosus & Ground & 1 & 1 \\
\hline Polydrusus undatus & Ground & 1 & 1 \\
\hline Sciaphilus asperatus & Ground & 2 & 8 \\
\hline Brachysomus echinatus & Forest & 6 & 15 \\
\hline Barypeithes pellucidus & Ground & 3 & 10 \\
\hline Brachyderes incanus & Forest & 4 & 33 \\
\hline Strophosoma capitatum & Ground & 5 & 10 \\
\hline Sitona suturalis & Ground & 6 & 90 \\
\hline Sitona sulcifrons & Ground & 2 & 3 \\
\hline Sitona lineellus & Ground & 3 & 4 \\
\hline Sitona cylindricollis & Ground & 2 & 2 \\
\hline Sitona humeralis & Ground & 2 & 3 \\
\hline Cleonis pigra & Ground & 1 & 1 \\
\hline Hypera meles & Ground & 2 & 2 \\
\hline Tychius stephensi & Ground & 1 & 1 \\
\hline Brachonyx pineti & Ground & 1 & 1 \\
\hline Gymnetron veronicae & Ground & 1 & 1 \\
\hline Rhyncolus ater & Forest & 1 & 1 \\
\hline Hylobius abietis & Forest & 3 & 13 \\
\hline Leiosoma deflexum & Forest & 1 & 1 \\
\hline Rhinoncus castor & Ground & 4 & 4 \\
\hline Ceutorhynchus erysimi & Ground & 1 & 1 \\
\hline Ceutorhynchus sulcicollis & Ground & 1 & 1 \\
\hline
\end{tabular}


Table 4 continued

\begin{tabular}{lllc}
\hline Species & Habitat category & Number of sites & Abundance \\
\hline Ceutorhynchus pallidactylus & Ground & 1 & 1 \\
Ceutorhynchus punctiger & Ground & 1 & 1 \\
Nedyus quadrimaculatus & Ground & 1 & 1 \\
Hylastes cunicularius & Forest & 1 & 1 \\
Hylastes opacus & Forest & 1 & 1 \\
Pityogenes chalcographus & Forest & 1 & 1 \\
Pityogenes quadridens & Forest & 1 & 1 \\
Pityogenes bidentatus & Forest & 3 & 3 \\
\hline
\end{tabular}

Red list categories (Gärdenfors 2010) are indicated in parenthesis after the species name. Species belonging to the carabid family is marked with an Asterisk

\section{References}

Andersson K (1995) Gravel-pits as refugia. Svensk Bot Tidskr 89:229-255 (in Swedish, abstract in English) Anon (2009) Aggregates. Production and resources 2008. The Geological Survey of Sweden, per. publ. 2009:3. ISSN 0283-2038 (in Swedish, abstract in English)

Arrhenius O (1921) Species and area. J Ecol 9:95-99

Báldi A (2008) Habitat heterogeneity overrides the species-area relationship. J Biogeogr 35:675-681

Bell LC (2001) Establishment of native ecosystems after mining-Australian experience across diverse biogeographic zones. Ecol Eng 17:179-186

Bergsten J (2007) Insekter i sand- och grustag. En inventering i Stockholms län 2006. Länsstyrelsen i Stockholms län, rapport 2007:21. ISBN: 978-91-7281-274-1 (in Swedish, summary in English)

Bzdon G (2008) Gravel pits as habitat islands: floristic diversity and vegetation analysis. Pol J Ecol 56:239-250

Chiarucci A, Viciani D, Winter C et al (2006) Effects of productivity on species-area curves in herbaceous vegetation: evidence from experimental and observational data. Oikos 115:475-483

Connor EF, McCoy ED (1979) The statistics and biology of the species-area relationship. Am Nat 113:791-833

Cook WM, Lane KT, Foster BL et al (2002) Island theory, matrix effects and species richness patterns in habitat fragments. Ecol Lett 5:619-623

de Vries HH, den Boer PJ, Djik van Th S (1996) Ground beetle species in heathland fragments in relation to survival, dispersal, and habitat preference. Oecologia 107:332-342

Dengler J (2009) Which function describes the species-area relationship best? A review and empirical evaluation. J Biogeogr 36:728-744

Drakare S, Lennon JJ, Hillebrand H (2006) The imprint of the geographical, evolutionary and ecological context on species-area relationships. Ecol Lett 9:215-227

Drewes B (1998) Colonization of a gravel pit in the Stade district by digger wasps, wild bees, and other aculeate hymenoptera (Hymenoptera: Aculeata). Drosera 98:45-68 (in German, abstract in English)

Dulias R (2010) Landscape planning in areas of sand extraction in the Silesian Upland, Poland. Landsc Urban Plan 95:91-104

Emanuelsson U (2009) The rural landscapes of Europe. How man has shaped European nature. Formas, Stockholm

Eriksson P, Frycklund I, Löfgren T et al (2005) The marma shooting range-a refuge for threatened insects. Ent Tidskr 126:1-20 (in Swedish, abstract in English)

Eversham BC, Roy DB, Telfer MG (1996) Urban, industrial and manmade sites as analogues of natural habitats for carabidae. Ann Zool Fenn 33:149-156

Ewers RM, Didham RK (2006) Confounding factors in the detection of species responses to habitat fragmentation. Biol Rev 81:117-142

Ewers RM, Thorpe S, Didham RK (2007) Synergistic interactions between edge and area effects in a heavily fragmented landscape. Ecology 88:96-106

Fletcher RJ Jr, Ries L, Battin J et al (2007) The role of habitat area and edge in fragmented landscapes: Definitively distinct or inevitably intertwined? Can J Zool 85:1017-1030 
Fredén C (2002) Geology. National atlas of Sweden. Bra Böcker, Höganäs

Freude H, Harde KW, Lohse GA, Lucht WH (1965-1994) Die käfer Mitteleuropas band 1-14. Goecke \& Evers, Krefeld (in German)

Frycklund M (2003) Rödlistade arter i Uppsala läns grustag. Länsstyrelsen i Uppsala län, meddelande nr 2003:2. ISSN 0284-6594. (in Swedish)

Gärdenfors U (ed) (2010) Rödlistade arter i Sverige 2010 - the 2010 red list of Swedish species. ArtDatabanken, SLU, Uppsala

Hansen V (1964) Fortegnelse over Danmarks biller 1. og 2. del. Entomol Medd 33:1-507 (in Danish)

Hansen V, Larsson SG (1965) Biller XXI. Snudebiller. Danmarks fauna G.E.C. Gads forlag, Copenhagen (in Danish)

He FL, Legender P (1996) On species-area relations. Am Nat 148:719-737

Kallimanis AS, Mazaris AD, Tzanopoulos J et al (2008) How does habitat diversity affect the species-area relationship? Global Ecol Biogeogr 17:532-538

Koch K (1989-1992) Die käfer Mitteleuropas. Ökologie. Band 1-3. Goecke and Evers, Krefeld. (in German)

Koeppel C, Spelda J, Rahmann H (1994) The butterflies (Lepidoptera) of four gravel pits at different succession stage in Upper Swabia. Jahreshefte der gesellschaft fuer naturkunde in Wuerttemberg 150:237-279 (in German, abstract in English)

Leps J, Smilauer P (2003) Multivariate analysis of ecological data using CANOCO. Cambridge University Press, Cambridge

Lindroth CH (1961) Svensk insektsfauna 9. Skalbaggar, Coleoptera, Sandjägare och Jordlöpare. Entomologiska föreningen i Stockholm, Stockholm (in Swedish)

Ljungberg H (2001) Jordlöpare som indikatorer vid övervakning av värdefulla naturmiljöer. Länsstyrelsen i Östergötland, rapport nr 2001:18 (in Swedish)

Ljungberg H (2002) Important habitats for red-listed ground beetles in Sweden. Ent Tidskr 123:167-185 (in Swedish, abstract in English)

Lövei GL, Magura T, Tóthmérész B et al (2006) The influence of matrix and edges on species richness patterns of ground beetles (Coleoptera: Carabidae) in habitat islands. Global Ecol Biogeogr 15:283-289

Lundberg S (1995) Catalogus coleopterorum Sueciae. Naturhistoriska riksmuseet, Stockholm

MacArthur RH, Wilson EO (1967) The theory of island biogeography. Princeton University Press, Princeton Magura T (2002) Carabids and forest edge: spatial pattern and edge effect. Forest Ecol Manag 157:23-37

Magura T, Ködöböcz V, Tóthmérész B (2001) Effects of habitat fragmentation on carabids in forest patches. J Biogeogr 28:129-138

Martikainen P, Kouki J (2003) Sampling the rarest: threatened beetles in boreal forest biodiversity inventories. Biodivers Conserv 12:1815-1831

Martin TE (1981) Species-area slopes and coefficients: a caution on their interpretation. Am Nat 118:823-837

Molander M (2007) Skalbaggar i skånska sand- och grustäkter. En undersökning av vilken täktmiljö som är gynnsammast för en rik skalbaggsfauna. Projektarbete, Malmö Borgarskola (in Swedish)

Niemelä J (2001) Carabid beetles (Coleoptera: Carabidae) and habitat fragmentation: a review. Eur J Entomol 98:127-132

Palm T (1948-1972) Svensk insektsfauna 47-53. Skalbaggar, Coleoptera, Staphylinidae 1-7. Entomologiska Föreningen i Stockholm, Stockholm (in Swedish)

Preston FW (1960) Time and space and the variation of species. Ecology 41:611-627

Rainio J, Niemelä J (2003) Ground beetles (Coleoptera: Carabidae) as bioindicators. Biodivers Conserv 12:487-506

Rosenzweig ML (1995) Species diversity in space and time. Cambridge University Press, Cambridge

Schiel FJ, Rademacher M (2008) Species diversity and succession in a gravel pit south of Karlsruheresults of a monitoring programme in the nature reserve 'Kiesgrube am Hardtwald Durmersheim'. Naturschutz und Landschaftsplanung 40:87-94 (in German, abstract in English)

Sörensson M (1983) Inventering av insektsfaunan. Grustag i Träkumla och stånga, nygårdsmyr, lövskogsområde i Sproge. Länsstyrelsen i Gotlands län (in Swedish)

Sörensson M (2006) Sand pits as valuable insect habitats: a case study from Trelleborg with three solitary bees new to Scandinavia (Hymenoptera: Apoidea). Ent Tidskr 127:117-134 (in Swedish, abstract in English)

ter Braak CJF, Smilauer P (1998) CANOCO reference manual and user's guide to Canoco for windows: Software for Canonican Community Ordination (version 4). Ithaca, NY

Tjørve E (2003) Shapes and functions of species-area curves: a review of possible models. J Biogeogr 30:827-835 
Triantis KA, Mylonas M, Lika K et al (2003) A model for the species-area-habitat relationship. J Biogeogr 30:19-27

Triantis KA, Nogués-Bravo D, Hortal J et al (2008) Measurements of area and the (island) species-area relationship: new directions for an old pattern. Oikos 117:1555-1559

Vries de HH (1994) Size of habitat and presence of ground beetle species. In: Desender K, Dufrêne M, Loreau M, et al (eds) Carabid beetles, ecology and evolution. Kluwer Academic Press, Dordrecht, pp 253-259

Widgren A (2005) Gravel pit becomes nature reserve for its botanical qualities. Svensk Bot Tidskr 99:265-268 (in Swedish, abstract in English)

Williams CB (1964) Patterns in the balance of nature. Academic Press, London 